Shruti Das*

\title{
TRAUMA AND TRANSGENDER SPACE IN ARUNDHATI ROY'S THE MINISTRY OF UTMOST HAPPINESS
}

Keywords: identity construction; transgender; trauma; Khwabgah; space.

Abstract: Social space largely decides the role of the human and the extent to which she controls or affects the physical environment. Any form of justice advocates and contends that instances of injustice are not simply arbitrary realities which occur in varying contexts. Rather, instances of injustice are the outcome of an institutional oppression and isolation which have set up an inevitable and sometimes invisible framework of colonization and the resultant anxiety and trauma by creating heterogenous spaces outside the accepted social space. More often than not, it is the effect of the gaze on the subject. In her novel The Ministry of Utmost Happiness (2017) Arundhati Roy, along with other stories, narrates the trauma of Anjum, a transgender, who was born a male, which forms one of the central threads of the narrative. Anjum, born Aftab, subsequently leaves her home to live with nine other transgenders who are 'othered' by the gaze and form a world of their own in a secluded, closely guarded and dilapidated home, the "Khwabgah" or "Palace of Dreams," in the lap of sophisticated New Delhi. Roy raises certain critical questions in this novel. One of them hitherto unexplored is the cultural trauma experienced by the transgender individual and the people associated with them. This paper attempts to bring to focus and analyse, with the tools of psychoanalysis, the effects of trauma in the construction of identity, specifically, with regard to the violated transgender psyche and their isolation in The Ministry of Utmost Happiness, with special focus on Anjum as a case in point, so that the readers can connect, understand and sympathize the homonormative individuals. This study draws on various theories of trauma like Julia Kristeva's theory of abjection and Lacan's theory of gaze.

Social space largely decides the role of the human and the extent to which she controls or affects the physical environment. Any form of justice advocates and contends that instances of injustice are not simply arbitrary realities which occur in varying contexts. Rather, instances of injustice are the outcome of an institutional oppression and isolation which have set up an inevitable and sometimes invisible framework of colonization and the resultant anxiety and trauma by creating heterogenous spaces outside the accepted social space. More often than not, it is the effect of the gaze on the subject. Hal Foster in discussing trauma in his essay “Obscene, Abject, Traumatic” brings into context Lacan's theory of gaze. He says,

... Lacan distinguishes between the look (or the eye) and the gaze, and to an extent like Merleau-Ponty in The Phenomenology of Perception (1945), he locates this gaze

* Berhampur University, Odisha; India. 
Trauma, Narrative, Responsibility

in the world. As with language in Lacan, then, so with the gaze: it preexists the subject, who, "looked at from all sides," is but a "stain" in "the spectacle of the world."' Thus positioned, the Lacanian subject feels the gaze as a threat, as if it queried him or her, and so it is that "the gaze, qua objet $a$, may come to symbolize this central lack expressed in the phenomenon of castration" ....(107)

The transgender is subject to such gaze that pre-exists her. Her isolation is due to her central lack that is reflected as a threat to her genetic castration and being different.

In her novel The Ministry of Utmost Happiness (2017) Arundhati Roy, along with other stories, narrates the trauma of Anjum, a transgender, who was born a male, which forms one of the central threads of the narrative. Anjum, born Aftab, subsequently leaves her home to live with nine other transgenders who are 'othered' by the gaze and form a world of their own in a secluded, closely guarded and dilapidated home, the "Khwabgah" or "Palace of Dreams," in the lap of sophisticated New Delhi. Roy raises certain critical questions in this novel. One of them hitherto unexplored is the cultural trauma experienced by the transgender individual and the people associated with them. While depicting the lives of transgenders and the injustice they suffer, she critiques the cultural attitude of treating something biologically natural as 'other' and how this othering affects the person. This paper attempts to bring to focus and analyse, with the tools of psychoanalysis, the effects of trauma in the construction of identity, specifically, with regard to the violated transgender psyche and their isolation in The Ministry of Utmost Happiness, with special focus on Anjum as a case in point, so that the readers can connect, understand and sympathize the homonormative individuals. This study draws on various theories of trauma like Julia Kristeva's theory of abjection and Lacan's theory of gaze.

Anjum was born as Aftab, a much-awaited boy child, to Jahanara Begum and Mulaquat Ali residents of Sahajahanabad, the walled city of Delhi. Jahanara Begum was shocked and horrified to discover that her son Aftab had a slightly unformed "girlpart” underneath his "boy-parts.” Her first reaction was that of shock, fear and rejection, "tofeel her heart constrict and her bones turn to ash.... Her third reaction was to recoil from what she had created while her bowels convulsed and a thin strip of shit ran down her legs” (Roy 7-8) She even contemplated killing herself and the child rather than face the stigma of having given birth to a queer child. Her dilemma was her crisis. Aftab defied classification or the binaries of gender. He was neither male nor female as he had both the penis and the vagina, though unformed. "In Urdu, the only language she knew, all things, not just living things but all things-carpets, clothes, books, pens, musical instruments- had a gender. Everything was either masculine or feminine, man or woman”.(8) The mother's trauma when she discovers that her son is in fact a Hijra, a Kinnar or a transperson, translates into the child as a sense of abjection, a breakdown of the subject and the object, an uncertainty, a corporeal reality that blurs the distinction between the Self and the Other. Giving birth to a Hijra/ transgender poses a threat to her existence and identity in society. She camouflages the real Aftab under clothes covering his genitals and keeping him close to her so that no one ever knows the truth.Such psychologyof abjection is explained by Kristeva at the beginning of her book Powers of Horror an Essay on Abjection: 
There looms, within abjection, one of those violent, dark revolts of being, directed against a threat that seems to emanate from an exorbitant outside or inside, ejected beyond the scope of the possible, the tolerable, the thinkable. It lies there, quite close, but it cannot be assimilated. It beseeches, worries, and fascinates desire, which, nevertheless, does not let itself be seduced. Apprehensive, desire turns aside; sickened, it rejects. A certainty protects it from the shameful-a certainty of which it is proud and holds on to it. But simultaneously, just the same, that impetus, that spasm, that leap is drawn toward an elsewhere as tempting as it is condemned. Unflaggingly, like an inescapable boomerang, a vortex of summons and repulsion places the one haunted by it literally beside himself. (1)

Jahanara Begum feels shame faced by a fact "beyond the scope of the possible, the tolerable, the thinkable". It becomes difficult for her to "assimilate" the fact that her child is queer and she decides to hide her shame. She doesn't even tell her husband the truth about the child. Her trauma lies in the Divine injustice that she is unable to comprehend. "It wasn't a real vagina after all, she told herself. It's passages were not open (she checked). It was just an appendage, a baby-thing. Perhaps it would close, or heal. Or go away somehow" (Roy 8).

Her anxiety to protect Aftab from the stain of the gaze and get him back as a normal boy urges her to visit the shrine of Hazrat Sarmad Shaheed to pray that her son be cured of the 'disorder.' Leonard Martin has cited eminent researchers in the field of compensation theory arising out of anxiety and a sense of social death. He says, "In their efforts to bring order to the vast range of social behaviours in which humans engage, a number of researchers have proposed the existence of very general motives. For example, researchers have suggested that individuals are motivated to maintain a favourable view of themselves ..., avoid social exclusion ..., escape the self ..., and reduce the anxiety brought on by awareness of their own death ..." (195)The integration of the history of Hazrat Sarmad Shaheed is in itself subversive. It is typical of Arundhati Roy to become intertextual in her narrative. “In Roy's work”, observes Jonathan Collins, "like in most postmodern, postcolonial fiction intertextuality plays an important role. There are numerous allusions to other literary works, religious texts, history, folklore, fairy tales, cinema, pop culture, etc. Intertextuality in postcolonial fiction is particularly important because it gives a sense of interconnectedness and emphasises the clash between the culture of the coloniser and the colonised." (2) The juxtaposition of the history of Sarmad with the story of Aftab, as an intertext, serves to emphasize the similarity between them. Bringing it into the narrative does not rupture the narrative, rather it functions as a contrast to the image that culturally the devotees have about him. The clash between cultures, the difference between that which is considered normal and what is real, is rendered stark and reality is subverted in the narration of the history of the Saint,about which Jahanara "had no idea" also that "Not all the visitors to Hazrat Sarmad Shaheed's dargah knew his story.”(9)Sarmad was himself a homosexual, who had travelled to Delhi from Persia in search of his love, "Abhay Chand, a young Hindu boy he had met in Sindh." (9) He was later beheaded on the steps of Jama Masjid by the Emperor Aurangzeb for 
"the offence caused by his apostasy" (9). Ignorant of these facts, overflowing with faith,Jahanara prayed to him "This is my son Aftab, ... I've brought him here to you. Look after him. And teach me how to love him" (11). Collins' coloniser and colonised can be transmuted into the oppressive normative society and the oppressed transgender person and her family in this context.

In her attempt to love her child she becomes aggressively possessive about Aftab and keeps him close to her. But once he starts going to school and grows older the truth about Aftab's homonormativity becomes self-evident.He becomes an accomplished singer of Hindustani Classical music under the tutelage of Ustad Hameed Khan and could sing "Chaiti and Thumri with the accomplishment and poise of a Lucknow courtesan”(12). People initially appreciated his artful singing, but he soon became a victim of the gaze. Aftab's being revolted to the teasing of the children at school, "He is a She. He's not a He or a She. He's a He and a She. She-He, He-She Hee! Hee! Hee!" (12) The teasing became intolerable for Aftab and his abjection was the revolt in his being against the children at school and he stopped going to the music classes and refused to go to school anymore. His first traumatic experience becomes a persistent memory refusing to be erased. On the other hand,Jahanara Begum's trauma was constituted differently. It was defined by the will to survive. Judith Herman's statement that psychological trauma can be understood only in a rather social context defines the trauma of Jahanara. She further affirms that "the restoration of social bonds begins with the discovery that one is not alone" (215) Hence, Jahanara decides to take her husband, Mulaqat Ali, into confidence and share the reality of their son.Mulaqat Ali is shocked at the revelation and takes some time to get over the news. Here again, Roy interrupts the narrative embedding into it the history of Mulaqat Ali's glorious lineage and past. It is relevant to recallAlexandra Podgornı ak's observation in another context, namely, Roy's first novel, The God of Small Things, which links the time play in the novel with magical realism: "In a manner typical . . . of magical realist fiction, Roy uses the technique of building a tale within a tale, persistently delaying climaxes, intermingling the past and the present” (261). This is especially true of her second novel, The Ministry of Utmost Happiness. The digression and intermingling of the past and the present serves in delaying the climax, which is the reaction of Mulaqat Ali to the news of his son's homonormativity.

Although, he was not materially affluent, Mulaqat Ali "always welcomed visitors into his tiny rooms with the faded grace of a nobleman. He spoke of the past with dignity ....” and pride.(Roy 14) He traced his lineage to the Mongol Emperor Changez Khan."He described how, in the thirteenth century, his ancestors had ruled an empire that stretched from the countries that now called themselves Vietnam and Korea all the way to Hungary and the Balkans, from Northern Siberia to the Deccan plateau in India, the largest empire the world had ever known"(14-15).Mulaqat Ali's fantasy world is badly threatened by his son's homonormative reality. His atavism juxtaposed against reality brings to the fore the enormity of trauma suffered by Mulaqat Ali who is afraid of his fantasy kingdom collapsing and therefore sets out to search for “a simple medical solution for their son's problem”(16). He takes Aftab to DrGulham Nabi, a sexologist, who examines him and says that, 


\section{Trauma, Narrative, Responsibility}

Aftab was not, medically speaking, a Hijra - a female trapped in a male body although for practical purposes that word could be used. Aftab, he said, was a rare example of a Hermaphrodite, with both male and female characteristics, though outwardly, the male characteristics appeared to be more dominant. He said he could recommend a surgeon who would seal the girl-part, sew it up. He could prescribe some pills too. But, he said, the problem was not merely superficial. ... there would be 'Hijra tendencies' that were unlikely to ever go away. (16-17)

Dr Nabi's report threatens to destroy the carefully constructed social identity of Mulaqat Ali. He suspends his belief in the medical truth and engages in raising money for Aftabs operation. He assigns Aftab's homonormative behaviour to some tendency which "can always be managed” (17) He is incapable of assimilating the truth when Aftab himself want to be a girl and moves into Khwagah to live with the nine other transgenders adopting a female name, Anjum. Mulaqat Ali's dignity is threatened, thus an abjection sets inside him "directed against a threat that seems to emanate from an exorbitant outside or inside, ejected beyond the scope of the possible, the tolerable, the thinkable" (Kristeva 1).Mulaqqat Ali appears to be the prototype of "the Lacanian subject" who "feels the gaze as a threat, as if it queried him or her, and so it is that the gaze, qua objet $a$, may come to symbolize this central lack expressed in the phenomenon of castration” (Foster 107) His existence seems to lack meaning and he feels castrated. We read:

Mulaqat Ali for his part was less able to accept the situation. His broken heart never mended. While he continued to give his interviews, he never spoke either privately or publicly of the misfortune that had befallen the dynasty of Changez Khan. He chose to sever all ties with his son. He never met Anjum nor spoke to her again. Occasionally they would pass each other on the street and would exchange glances, but never greetings. Never. (25)

Jessica Gildersleeve in her book Elizabeth Bowen and the writing of Trauma discusses various models of psychological trauma, including that of Sigmund Freud, and writes "that trauma is a kind of psychological wounding caused by an event so extreme that it cannot be immediately assimilated" (3). Aftab's trauma, caused by the incident at school and the reaction of his father, was such that he could not bear to stay in the house any longer. In addition to that, "His body had suddenly begun to wage war on him" (23-4). His maleness began to manifest itself in the form of body hair, cracked voice and a tall muscular body which caused him anguish as he could not come to terms with it.

In a panic he tried to remove the hair on his face and body with Burnol - burn ointment that made dark patches on his skin. He then tried Anne French crème hair remover that he purloined from his sisters... He plucked his bushy eyebrows into thin, asymmetrical crescents with a pair of home-made tweezers.... He developed an Adam's apple that bobbed up and down. He longed to tear it out of his throat. Next came the unkindest betrayal of all- the thing that he could do nothing about. His voice broke A deep, powerful man's voice appeared in place of his sweet, high voice. He was repelled and scared himself each time he spoke. He grew quiet, and would speak only as a last resort, after he had run out of other options. He stopped singing. (24) 
Aftab's body, and the physical changes due to his adolescence, became a site of torture for him. The psychological wounding caused by his body's natural physical changes was extreme. The words "panic", "longer to tear it out," "unkindest betrayal," "he was repelled" and "scared himself" in the discourse of the passage cited above "is a narrative of suffering and horror, not only because the "themes" are there, as such, but because his whole narrative stance seems controlled by the necessity of going through abjection, whose intimate side is suffering” (Kristeva 140).

Aftab comes to learn of a home or a "Haveli" called the Khwabgah, the House of Dreams, where nine transgenders live in harmony. The Khwabgah offered "another universe," another space, through an "ordinary doorway". The residents were members of the trangender or 'Hijra community' which was ruled by a Chief, UstadKhulsoom Bi, with its own rules and rituals. In fact, Khwabgah was a space that would not possibly have what Lacan calls the gaze, the maleficent "evil eye", the agent of disease and death, having the power to castrate. "It is a question of dispossessing the evil eye of the gaze, inorder to ward it off. The evil eye is the fascinum [spell], it is that which has the effect of arrestingmovement and, literally, of killing life.... It is precisely one of the dimensions in which the power of thegaze is exercised directly" (Lacan118).Khwabgah was a paradise that disposed the evil eye of the gaze and warded it off. The residents breathed in a different world, altogether different from the real world that existed outside of it, "Hijras called Duniya, the World" (Roy 24).Judith Herman analyses the traumatic symptoms of victims and argues that psychological trauma encompasses individual experience and can be understood only in a social context. She further affirms that "the restoration of social bonds begins with the discovery that one is not alone" (215). In utter abjection of the world one night Aftab "stole some money and his sister's nicer clothes and moved into the Kwabgah... only a few hundred yards from where his family had lived for centuries" (24-5).He stepped into a completely different world where the binaries did not hold and where the homonormative was considered the norm. The night after his entry he was "presented with a green Khabgah dupatta (veil) and initiated into the rules and rituals that formally made him a member of the Hijra community. Aftab became Anjum, disciple of Ustad Kulsoom Bi of the Delhi Gharana [guild]” (25).

She was able to collectively ward off the evil eye or the gaze by coming out as a Hijra and moving into a defined transgender space, where she could dress as a woman and behave as such without having to suffer the pre-existing gaze. The narrator discloses that she may not be as beautiful as her co-resident Bombay Silk, "but she was sexier, more intriguing, handsome in the way some women can be."(26) She completely assimilated into the community and learned the codes of the guild, "to exaggerate the swing in her hips when she walked and to communicate with the signature spread-finger Hijra clap that went off like a gunshot” (27). Anjum happily recast her life, until, on her eighteenth birthday, when she "dreamed she was a new bride on her wedding night. She awoke distressed to find that her sexual pleasure had expressed into her beautiful new garment like a man's. ... the humiliation she felt had never been so intense.” (27). For Anjum this characterises another traumatic event. "The historical power of the trauma is not just that the experience is repeated after its forgetting, but that it is only in and through its inherent forgetting that it is first 
experienced at all” (Gildersleeve 4). Anjum's repulsion of her body and resultant trauma is manifest in her distress: "She sat in the courtyard and howled like a wolf, hitting herself on her head and between her legs, screaming with self-inflicted pain" (Roy 27). Some of the other Hijras in Khwabgah had undergone castration, they had had surgery to remove their penis. Anjum goes to one Dr Mukhtar to subject herself to surgery and treatment that would change her gender. "He said he could remove her male parts and try to enhance her vagina. He also suggested pills that would un-deepen her voice and help her develop breasts” (28). Kristeva's argument applies to the psychological state of Anjum. She writes,

when narrated identity is unbearable, when the boundary between subject and object is shaken, and when even the limit between inside and outside becomes uncertain, the narrative is what is challenged first. If it continues nevertheless, its makeup changes; its linearity is shattered, it proceeds by flashes, enigmas, short cuts, incompletion, tangles, and cuts. At a later stage, the unbearable identity of the narrator and of the surroundings that are supposed to sustain him can no longer be narrated but cries out or is descried with maximal stylistic intensity (language of violence, of obscenity, or of a rhetoric that relates the text to poetry). The narrative yields to a crying-out theme that, when it tends to coincide with the incandescent states of a boundary-subjectivity that I have called abjection, is the crying-out theme of suffering horror. (141)

Anjum suffers horror. Her linearity of her constructed identity is shattered. The unbearable identity of Anjum and her situation that are supposed to sustain her can no longer be narrated but cries out or is descried with maximal stylistic intensity, language of violence, of pain and a rhetoric that relates to her subjectivity. She desires motherhood and adopts an abandoned girl child and names her Zainab. She brings Zainab to Khwabgah and loves her fiercely. She tells her stories at bedtime: "They were Anjum's somewhat maladroit attempt to make up for lost time, to transfuse herself into Zainab's memory and consciousness, to reveal herself without artifice, so that they could belong to each other completely. As a result she used Zainab as a sort of dock where she unloaded her cargo - her joys and tragedies, her life's cathartic turning points”(Roy 32) Anjum performs a fabricated gender identity which contributes to further trauma. It is pertinent in the context to cite Jamili and Roshanzamir's discussion of Judith Butler's argument regarding gender identity: "Butler believes that gender is constructed through acts, traits, behavior affected by the internal essence and is exhibited by the body that is the cause of principles of one's identity. Because gender is itself performatively constituted, those principles of one's identity are not made in real domain by actual principles and only convey corporeal signs based on gender performativity.” (115) Anjum's gender which defies the binaries of male and female seeks to perform motherhood which is a purely female act. Thus, she attempts to carve out her identity as a culturally female person. According to Cathy Caruth, a noted critic in trauma studies, "trauma, ... does not simply serve as record of the past but precisely registers the force of an experience that is not yet fully owned” (150). Zainab falls ill and Anjum silently accuses Saeeda, another inmate of Khwabgah, of sorcery. Theatrical and emotional she goes to 
Khadim, a maullavi, who manages to convince Anjum to visit the dargah of Hazrat Gharib Nawaz in Ajmer to seek protection for Zainab.

Zakir Mian, a friend of Anjum's father, accompanies her to Ajmer and from thee they travel to Ahemedabad in Gujarat where Zakir Mian has some business with his wife's family. A constant victim of post-traumatic stress “Anju was prepared to travel with him to Ahmedabad rather than risk the harassment and humiliation (of being seen as well as being unseen) that she would have to endure if she travelled back on her own from Ajmer" (Roy 43) Anjum's fear resides outside of his body, in the fact that he does not confirm to the binaries of gender. The fear of humiliation and harassment which she experiences translates to fear and justifies the violence inflicted on his psyche from outside. She has internalised injustice and fear which turns self destructive. The narrative weaves the temporal politics of the Gujarat riots of 2002 into the fabric of the central narrative and religion becomes the site of trauma. The burning of a train on $27^{\text {th }}$ of February 2002 in Gujarat, a western state of India, caused outbreak of violence in Ahmedabad for three months, during which 790 Muslims and 254 Hindus were officially reported dead. (2002 Gujarat Riots) Roy’s political narrative at this point involves Anjum in a double bind of trauma as she interrogates the justification of violence in the name of religion. "The police arrested hundreds of Muslims ... from the area around the railway station under the new terrorism law and threw them into prison” (Roy 44). Two months after the riot Zakir Mian's son goes in search for his father and Anjum. He is unable to trace his father but finds Anjum in a small refugee camp inside a mosque in the outskirts of Ahmedabad in the men's section. "She had had a haircut. ... was dressed ... in a pair of dark brown men's terry cotton trousers and a checked, short-sleeved safari shirt" (46). In the "Introduction" to The Unspeakable: Representations of Trauma in Francophone Literature and Art Nossery and Hubble state that "trauma is a separating force that can render its victims silent or incapable of grieving. Horrific events, experienced in community or individually, encumber the victim as they resurge unexpectedly and continually in the present. Past trauma constantly contaminates the present, and the present is haunted even when resistant to the past. The victim suffers the aftershocks and struggles to accommodate the enduring physical and mental anguish" (1). A “related paradox involves the freezing of time at one instant, locking the subject in the past moment of trauma; yet alongside the freezing there is a false sense of movement or unfreezing, as the memory returns again and again to haunt the present" (Outka 26) Anjum is frozen and unmoved by the tears or affection of the residents of Khwabgah. It is as if it is an ordeal for her to put up with empathy and concern.

She returns physically to her transgender way of live but refuses to talk about what happened or answer any question about Zakir Mian. The unspeakable trauma is represented in her teaching Zainab the Hindu hymns, which she says would come handy in protecting herself someday. Trauma theorists opine that, "Traumatic experience may be unspeakable, but it is not necessarily unrepresentable. Even if pain is a corporal expression of trauma, it can further isolate the victim with its crushing reminders of the event. In cases of hideous violence such as genocide, torture, imprisonment, and rape, conveying the experience through alternate modes of expression may, if not heal wounds left gaping for years and even decades, at least help the victim survive”( Nossery and Hubble 1). Quietness and silence gave way to 
restlessness and an uprising against what she felt was "a lifetime of spurious happiness she felt she had been sentenced to" (Roy 57) She burns everything she had once treasured and rubs the cooled ash into her face and hair as an act of denouncing the happiness she had once sought inside the walls of Khwabgah. Karin Fierke's in her essay "Whereof We Can Speak, Thereof We Must Not Be Silent: Trauma, Political Solipsism and War," explains that grief is "embedded in a community, while trauma and emotional numbing correspond with a breakdown of community and an isolation, which may give rise to solipsism” (472). Trauma dislocates Anjum, she packs her meagre belongings and moves to a completely different space, a space generally avoided by people, a graveyard where her isolation would be complete.

The narrative transforms and renders pain through images and discourse: "Her desolation protected her. Unleashed at last from social protocol, it rose up around her in all its majesty - a fort, with ramparts, turrets, hidden dungeons and walls that hummed like an approaching mob. She rattled through its gilded chambers like a fugitive absconding from herself. ... She tried to shut the door on Zakir Mian, lying neatly folded in the middle of the street... She tried to forget the way he looked at her" just before he died (Roy 61). The narrative leads the reader to witness trauma and its various manifestations, first, in the socio-cultural space where gender binary is acceptable but any violation of strict binaries are not only questioned but subjected to the stain of the evil gaze. Secondly, the narrative exposes the reader to socio-political trauma which scars a human beyond repair. Language in this novel is not simply a means of communication through words and gestures only juxtaposing atavistic tales with the present but an expression which links various kinds of trauma each time offering a space, both physical and mental, for recovery. In conclusion we can adapt Judith Herman's words and say in this context that through participatory language Roy's novel generates within the reader a feeling of empowerment and a critical consciousness to protest, to parody and to empathize with the centuries of wounds inflicted on the transgender persona.

\section{Works Cited:}

2002 Gujarat Riots. https://en.wikipedia.org/wiki/2002_Gujarat_riots Web. 10.Sept. 2019

Caruth, Cathy. Trauma: Explorations in Memory. Blatimore: The Johns Hopkins UP, 1995.

Colins, Jonathan. “Arundhati Roy's The God of Small Things as a Postmodern Novel” Scribd. Scribd, n.d. Web. 5 Oct. 2019.

Fierke, Karin. "Whereof We Can Speak, Thereof We Must Not Be Silent: Trauma, Political Solipsism and War”. Review of International Studies 30.4 (October 2004), 472.

Foster, Hal. Obscene, Abject, Traumatic. Fall 1996: 107-24.

Gildersleeve, Jessica. Elizabeth Bowen and the Writing of Trauma: The Ethics of Survival, BRILL, 2014: 1-12. ProQuest Ebook Central,

http://ebookcentral.proquest.com/lib/khallikoteunivebooks/detail.action?docID=168 6956. 
Trauma, Narrative, Responsibility

Herman, Judith Lewis. Trauma and Recovery: The Aftermath of Violence from Domestic Abuse to Political Terror. New York: Basic Books, 1997.

Jacques Lacan, The Four Fundamental Concepts of Psychoanalysis, trans. Alan Sheridan (New York: W. W. Norton, 1978): 72-5.

Jamili, Leila Baradaran, and Ziba Roshanzamir. "Postmodern Feminism: Cultural Trauma in Construction of Female Identities in Virginia Woolf's The Waves.” Advances in Language and Literary Studies, vol. 8, no. 4: 114-20.

Kristeva, Julia. Powers of Horror: An Essay on Abjection. Trans. Leon S. Roudiez. Columbia University Press, 1982.

Lacan, Jacques. The Four Fundamental Concepts of Psychoanalysis, trans. Alan Sheridan. New York: W. W. Norton, 1978.

Martin, Leonard L. I-D Compensation Theory: Some Implications of Trying to Satisfy Immediate-Return Needs in a Delayed-Return Culture. Psychological Inquiry 1999, Vol. 10, No. 3: 195-208.

Nossery, Névine El and Amy L. Hubbell. Eds. The Unspeakable: Representations of Trauma in Francophone Literature and Art Cambridge Scholars Publishing, 2013.

Outka, Elizabeth. Trauma and Temporal Hybridity in Arundhati Roy's The God of Small Things. Contemporary Literature, vol. 52, no.1, Spring 2011: 21-53.

Podgo'rnı'ak, Alexandra. "Magical Realism, Indian-Style, or the Case of Multiple

Submission: The God of Small Things by Arundhati Roy." Missions of Interdependence: A Literary Directory. Ed. Gerhard Stilz. New York: Rodopi, 2002: 255-63.

Roy, Arundhati. The Ministry of Utmost Happiness. New Delhi: Penguin, 2017. 